\title{
EVOLUTION OF ANTIOXIDANT PROPERTIES OF ORANGE BEVERAGE DURING STORAGE: EFFECTS OF TIME AND TEMPERATURE
}

\author{
- Short communication -
}

\author{
Ouahiba Soufi ${ }^{1}$, Mostapha BACHIR-BEY*,2, Saida $\operatorname{KESSI}^{1}$, Djamila GANI ${ }^{1}$, Nourredine \\ TOUATI $^{3}$
}

\author{
${ }^{1}$ Faculté SNV, Département des Sciences Alimentaires, Université de Bejaia, 06000 Bejaia, Algérie \\ ${ }^{2}$ Laboratoire de Biochimie Appliquée, Faculté SNV, Université de Bejaia, 06000 Bejaia, Algérie \\ ${ }^{3}$ Faculté des Sciences et de la Technologie, Université de Bordj Bou Arreridj, 34000 Bordj Bou \\ Arreridj, Algérie
}

\begin{abstract}
Fruit beverages are the most consumed refreshing products worldwide. The quality of these drinks is not only influenced by the initial composition of the product but also by conditions and duration of storage. The purpose of the present investigation was to evaluate the incidence of two conservation parameters (temperature and time) on some bioactive compounds (phenolic, flavonoid, and carotenoid contents) and antioxidant capacity, measured by free radical scavenging activity (RSA) and ferric reducing power (FRP), on orange beverage during storage. The industrial drinking product freshly procured were subjected to storage under variable temperatures $\left(5,25,35\right.$, and $\left.45^{\circ} \mathrm{C}\right)$ then analyses of bioactive compounds contents and antioxidant activity were performed periodically $(0,10,20$, and 30 days). The results showed that the initial orange beverage was endowed with interesting phenolic compound contents and considerable antioxidant potential. In the exception of $5{ }^{\circ} \mathrm{C}$, which provided steady antioxidant parameters, all other temperatures induced decreases of analyzed phytochemicals and antioxidant activities proportionally with raising of storage temperature. The duration of storage for the temperatures 25,35 , and $45{ }^{\circ} \mathrm{C}$ also affected negatively antioxidant parameters in a proportional manner to time. The orange beverage was an interesting natural source of bioactive compounds but the duration of storage in relation to temperature must be chosen properly.
\end{abstract}

Keywords: Orange beverage, Storage, Temperature, Time, Antioxidant

\section{INTRODUCTION}

Several epidemiological studies have demonstrated that the consumption of fruits, vegetables, and their products had a positive effect on the reduction of numerous diseases. This is related to the presence of antioxidant compounds such as polyphenols, essential oils, carotenoids, and vitamins (Janciauskiene, 2020; Liu, 2003; Sharifi-Rad et al., 2020).

Through the last twenty years particularly, the interest in the consumption of fruit juices is in continual increase because of their nutrient composition and their freshness. The more consumed fruit beverages are produced from orange due they are appreciated by the most consumers and to the high production of orange that is estimated in 2019 at 77 million tons worldwide (FAOSAT, 2021).

However, the conditions adopted during storage can cause alterations in their qualitative and quantitative composition; therefore, their nutritional quality (bioactive compounds) could strongly decrease if the storage is not adequate (Chen \& Gao, 2021; Saad et al., 2020).

In this work, the evaluation of the impact of different temperatures $\left(5,25,35\right.$, and $\left.45^{\circ} \mathrm{C}\right)$ and the duration $(0,10,20$, and 30 days) of storage on antioxidant contents (total phenolic compounds, flavonoids, and carotenoids) and antioxidant capacity of orange beverage was performed.

Received: 05.10.2021

Accepted in revised form: 02.12 .2021

${ }^{1}$ Corresponding author. E-Mail address: mostapha.bachirbey@univ-bejaia.dz 


\section{MATERIALS AND METHODS}

\section{Sampling and storage of orange beverage}

The orange beverage samples were procured from an agro-food industry located in the Bejaia department (Algeria). The product was manufactured in $30 \mathrm{cL}$ PET bottles. A sufficient quantity from a fresh production was transported to the laboratory (Food Biochemical, University of Bejaia, Algeria) using isothermal bags. The provided beverage bottles were aliquoted and stored at different temperatures using a refrigerator for 4 ${ }^{\circ} \mathrm{C}$ and ovens set at 25,35 , and $45^{\circ} \mathrm{C}$. The drink was analyzed using three independent samples before storage $(\mathrm{T}=0)$ and after every 10 days $(\mathrm{T}=10,20$, and 30 days) for one month.

\section{Extract preparation}

The preparation of extracts was performed on the same day of the beverage production $\left(\mathrm{t}_{0}\right)$ and after each storage period at different temperatures for 10 , 20, and 30 days. Seven milliliters of the sample were mixed with the same volume of solvent (methanol). After stirring, the mixtures were centrifuged at $5000 \mathrm{rpm} / 20 \mathrm{~min}$, then filtered and obtained extract was stored in the refrigerator until analysis.

\section{Antioxidant quantifications}

\section{Total phenolic contents (TPC)}

TPC were measured following the method reported by Kähkönen et al. (1999). An aliquot of extract $(200 \mu \mathrm{L})$ was homogenized with Folin-Ciocalteu and $\mathrm{Na}_{2} \mathrm{CO}_{3}(7.5 \%)$. The absorbances were read after $1 / 2$ hour at $725 \mathrm{~nm}$ (Uvi-mini1240, ShimadzuSuzhou, China). TPC were calculated as milligrams of gallic acid equivalents per 100 milliliters of beverage (mg GAE/100 ml).

\section{Flavonoid contents}

The flavonoid contents were estimated based on the method complexion with $\mathrm{AlCl}_{3}$ (Djeridane et al., 2006). One milliliter of the extract was added to the same volume of aluminum chloride $(2 \%$ in methanol) then the mixture was allowed to stand for $15 \mathrm{~min}$. The absorbance was read at $430 \mathrm{~nm}$.

\section{RESULTS AND DISCUSSION}

\section{Antioxidant contents}

The statistical analysis revealed that phenolic contents of orange beverages decreased gradually (+05) using temperatures of 25 and $35^{\circ} \mathrm{C}$. However, TPC were stable at $5{ }^{\circ} \mathrm{C}$ during the period of storage (Figure 1). These results agree with those of SuárezJacobo et al. (2012) who found that the degradation
Quercetin was taken as a standard to establish the calibration curve and the concentrations were calculated as $\mathrm{mg} \mathrm{QE} / 100 \mathrm{ml}$.

\section{Carotenoïds}

The extraction of carotenoids was done referring to Soto-Zamora et al. (2005). Beverage orange extract $(4 \mathrm{ml})$ was homogenized with extraction solvent mixture $(20 \mathrm{ml} ; 10 \mathrm{ml}$ hexane $/ 5 \mathrm{ml}$ acetone $/ 2.5 \mathrm{ml}$ ethanol). The obtained mixture was homogenized for $3 \mathrm{~min}$ and centrifuged (4000 rpm/20 min). After that, the upper hexanic layer was recovered and the absorbance was measured at $450 \mathrm{~nm}$. The carotenoid contents were calculated as milligrams equivalent of $\beta$-carotene per $100 \mathrm{ml}$ of beverage ( $\mathrm{mg}$ $\beta-\mathrm{CE} / 100 \mathrm{ml})$.

\section{Antioxidant activities \\ Ferric reducing power}

FRP was evaluated according to Gülçin et al. (2002). $250 \mu \mathrm{L}$ extract was homogenized with 250 $\mu \mathrm{L}$ of phosphate buffer $(0.2 \mathrm{M}, \mathrm{pH} 6.6)$ and $250 \mu \mathrm{L}$ of $1 \% \mathrm{~K} 3 \mathrm{Fe}(\mathrm{CN}) 6$. The obtained solution was incubated $20 \mathrm{~min}$ at $50{ }^{\circ} \mathrm{C}$. Then $250 \mu \mathrm{L}$ of $10 \%$ TCA and $200 \mu \mathrm{L}$ of $0.1 \% \mathrm{FeCl}_{3}$ were added. Absorbances were read at $700 \mathrm{~nm}$ and the FRP was expressed as milligrams of ascorbic acid equivalents per $100 \mathrm{ml}$ beverage (mg AAE/100 ml).

\section{DPPH antioxidant assay}

The antiradical capacity of extract was estimated as described by Bachir bey et al. (2014). $100 \mu \mathrm{L}$ extract was added to $900 \mu \mathrm{L}$ of $60 \mu \mathrm{M} \mathrm{DPPH}$ solution (1,1-diphenyl-2-picrylhydrazyl radical). The absorbance was recorded after $30 \mathrm{~min}$ at 517 $\mathrm{nm}$ and the results were reported as milligrams of ascorbic acid equivalents per $100 \mathrm{ml}$ of beverage (mg AAE/100 ml).

\section{Statistical analyses}

Statistical analyses of results were treated with Statistica-V05.5. The two-way analysis of variance (MANOVA-LSD test) was achieved in order to determine the statistical differences among means according to the time and the temperature regarding each analyzed parameter. $p$-values $<0.05$ were considered statistically significant.

rate of phenolic compounds at $5{ }^{\circ} \mathrm{C}$ was insignificant ( $p$ <0.05). The initial level of TPC in samples was $12.41 \mathrm{mg} \mathrm{GAE} / 100 \mathrm{ml}$ of beverage. This obtained concentration was lower than that revealed by Klimczak et al. (2007), who used chromatography (HPLC) for quantification; this can probably be due to the sensibility of the used method. 


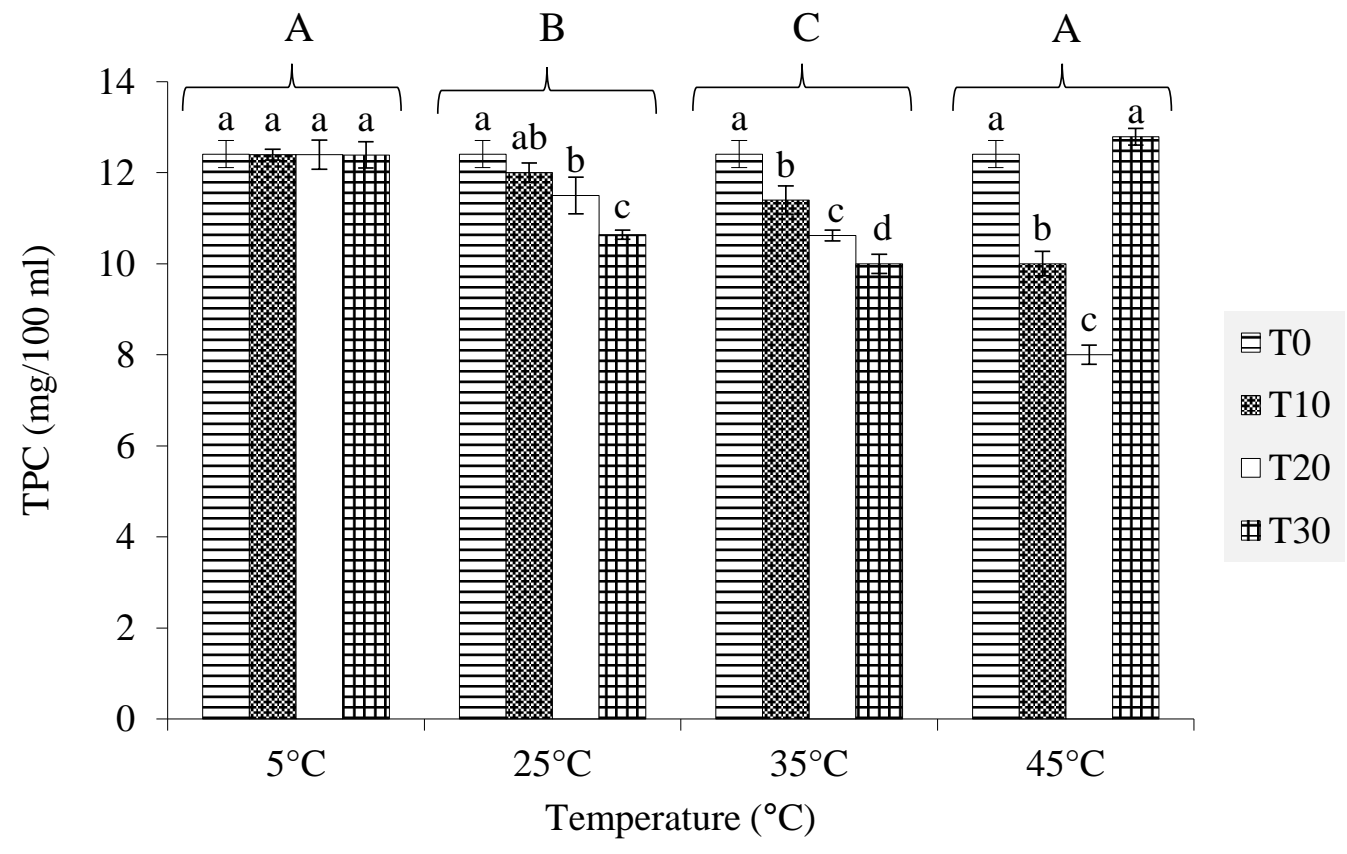

Figure 1. Influence of storage parameters on TPC of orange beverage.

Individual (lower-case letter) or grouped (upper-case letter) results with the same letters were statistically similar $(p<0.05$, MANOVA-LSD test).

The cultivar of orange used for the preparation of beverages can also affect the concentration of phenolic contents. Su et al. (2019) were remarked also that the TPC of lychee juice might be well conserved under storage at $4{ }^{\circ} \mathrm{C}$.

Through the first twenty days of storage under 45 ${ }^{\circ} \mathrm{C}$, polyphenol concentrations were significantly decreased by 14 and $22 \%$ for the first 10 and 20 days, respectively. This can be explained by the sensibility of such compounds for high temperatures. However, at the end of storage (30 days), the content of these compounds showed a significant increase. This was probably due to the formation of some compounds that accrue with browning reactions in particular melanoidins recognized for their abilities to react with Folin-Ciocalteu reagent (Vinson et al., 2001; Bachir bey et al., 2017)

During the storage of strawberry beverage, it has been observed that phenolics composition remained steady until the fifteenth day of storage at ambient temperature (about 27 to $30{ }^{\circ} \mathrm{C}$ ) and even thirtiethday under refrigeration (Álvarez-Fernández et al., 2016), indicating that the temperature and time were closely related parameters.

The concentration of flavonoids gradually decreased as the temperature of storage increased (Figure 2); the highest contents were noted during the storage at $5{ }^{\circ} \mathrm{C}$, while, the lowest ones were observed at $45{ }^{\circ} \mathrm{C}$. The diminishing in flavonoids content during storage under high temperature could be explained by the sensibility of these substances to heat. Kırca and Cemeroğlu (2003) recorded similar observations concerning the evolution of anthocyanins, a subclass of flavonoids, during the storage of orange juice at temperatures of 5,20 , and $37^{\circ} \mathrm{C}$.

It was well established that flavonoids were highly degraded with temperature. The processing temperature was shown in most cases that the contents of these compounds were reduced at levels sometimes exceeding a half (Ahmed \& Eun, 2018).

\section{Carotenoids}

The statistical analysis didn't reveal any significant differences regarding carotenoid contents of samples stored at $5{ }^{\circ} \mathrm{C}$ (Figure 3), this stability can be explained by the high content of vitamin $\mathrm{C}$ which acts as a protective agent against the harmful oxygen in the beverage (Choi et al., 2002). The results of this study were similar to those of Plaza et al. (2011) who showed that orange juice carotenoids were stable at $4{ }^{\circ} \mathrm{C}$ during 40 days of storage, but different to that conducted on carrot beverage stored for 28 days that has demonstrated that carotenoids content was reduced even using a temperature of 4 ${ }^{\circ} \mathrm{C}$ (Liu, 2003). 


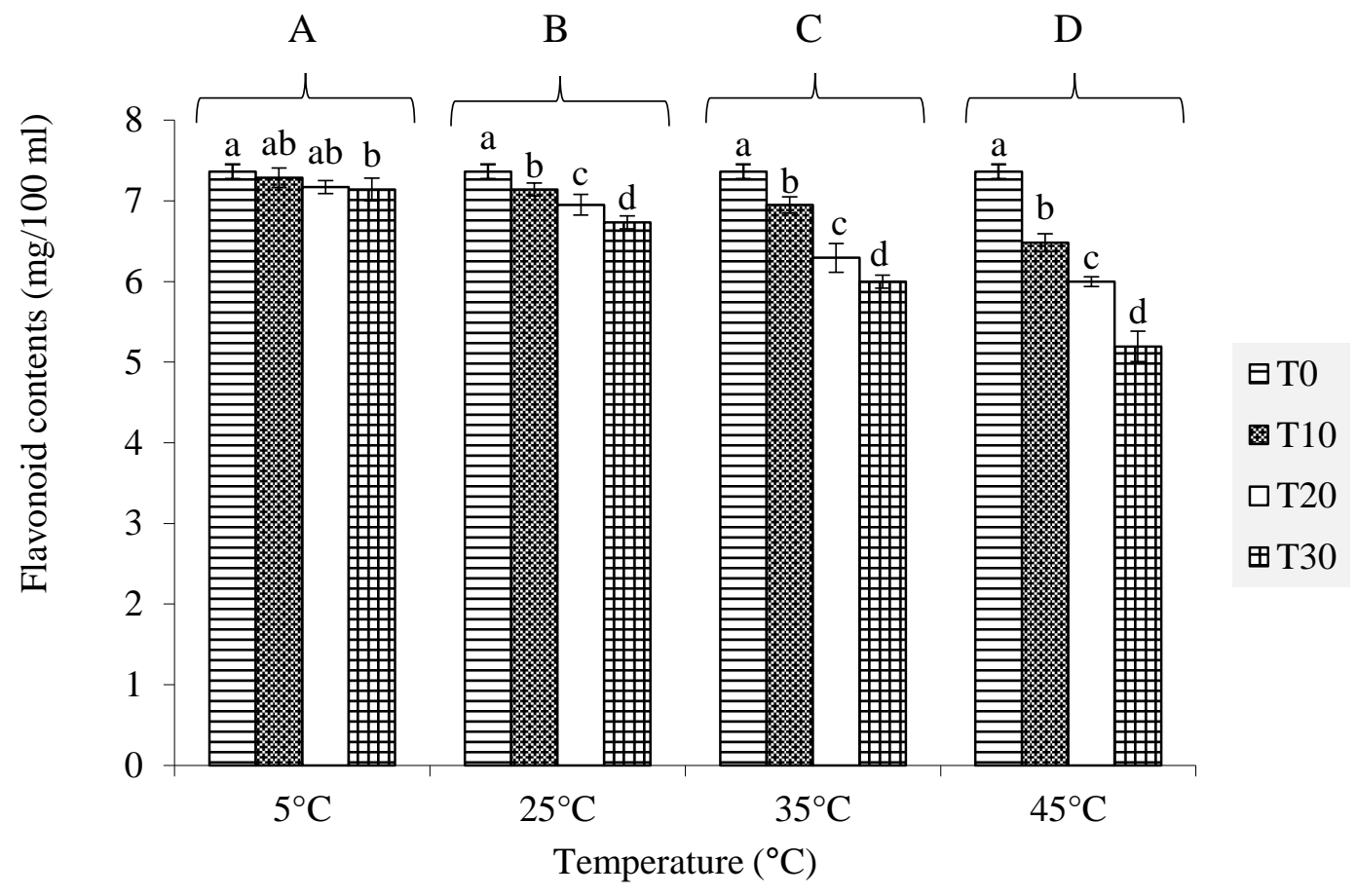

Figure 2. Influence of storage parameters on flavonoids concentration of orange beverage.

Individual (lower-case letter) or grouped (upper-case letter) results with the same letters were statistically similar ( $p<0.05$, MANOVA-LSD test).

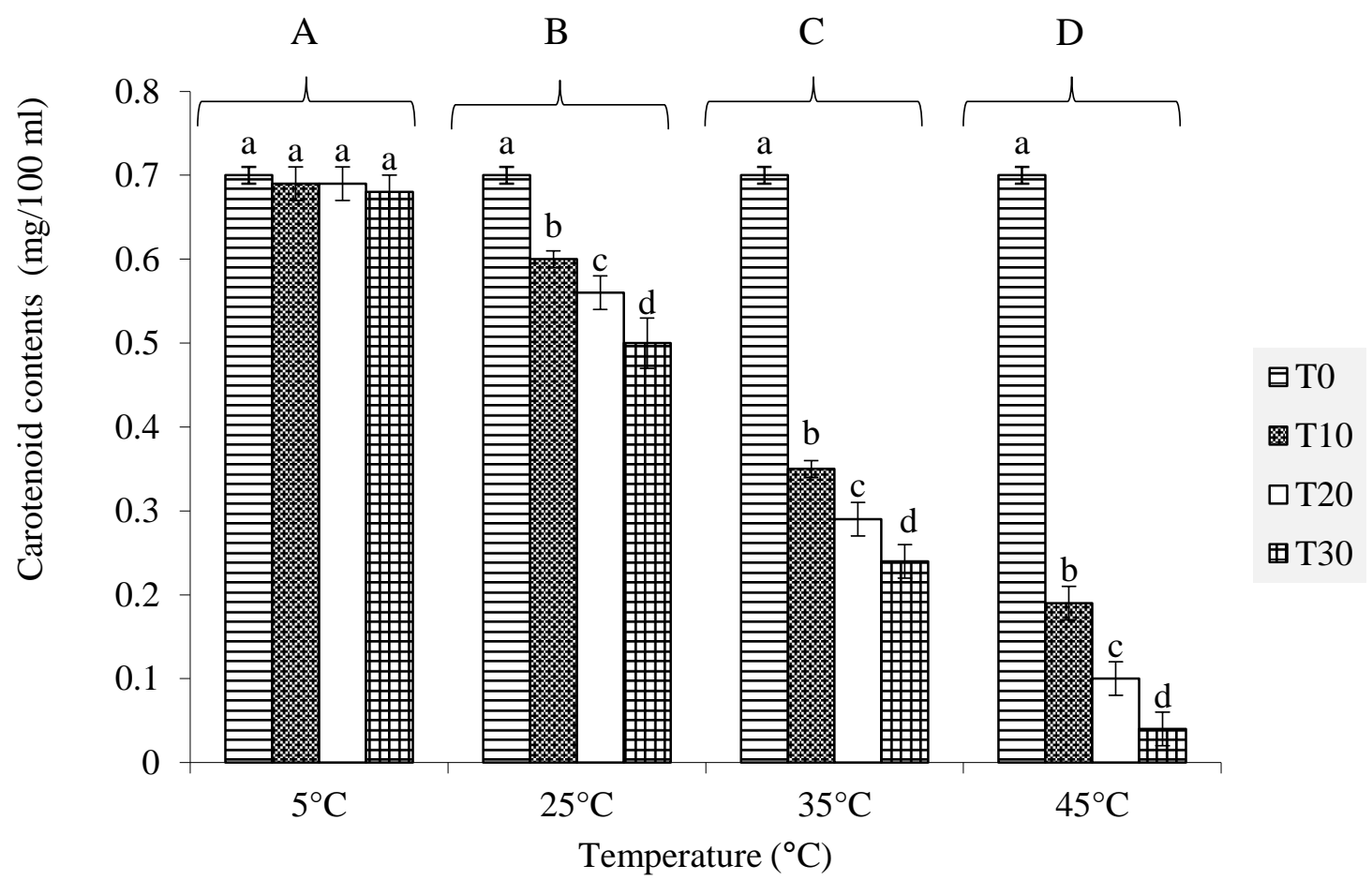

Figure 3. Influence of storage parameters on carotenoids concentration of orange beverage.

Individual (lower-case letter) or grouped (upper-case letter) results with the same letters were statistically similar $(p<0.05$, MANOVA-LSD test).

In contrast, the content of these compounds marked significant gradual diminutions under 25,35 , and 45 ${ }^{\circ} \mathrm{C}$ during the storage period; the lowest carotenoids content $(0.04 \mathrm{mg} / 100 \mathrm{ml})$ was observed at $45^{\circ} \mathrm{C}$ by the end of storage. This observation could be explained by the sensitivity of polyene chains that undergo isomerizations followed then by a series of oxidation reactions, which are promoted by high temperature and other parameters such as moisture and dissolved oxygen (Rodriguez-Amaya, 1997). 
Lin and Chen (2005) reported the same finding in the study of tomato juice storage.

The processing and storage time of numerous products have been demonstrated a decrease in bioactive compounds and antioxidant properties. The bioactive compounds of cactus pear juice (betacyanins) undergo degradation during the storage proportionally to temperature increase and storage duration (Bassama et al., 2021). The decrease of both polyphenols and antioxidant capacity were observed during the conservation of fruit nectars (Touati et al., 2014) and mangaba jelly (Zitha et al., 2021).

\section{Antioxidant activities}

Many antioxidants act as reducing agents that remove the prooxidant compounds such as reactive oxygen species and metal ions responsible for the initiation of radical reaction chains. The beverage set at $5{ }^{\circ} \mathrm{C}$ indicated no significant differences in reducing power during all the storage period (Figure 4). Reducing power was gradually reduced by temperature increasing $\left(25<35<45^{\circ} \mathrm{C}\right)$ and storage time progressing $(0<10<20<30$ days $)$. The decrease in reduction property of orange beverage was linked to the decrease of bioactive contents that was in agreement with the results obtained in some other investigations (Shams Najafabadi et al., 2021; Kausar et al., 2020; Porto et al., 2017).

DPPH assay is a common method used to evaluate the antioxidant capacity of extracts. This basic and rapid test is considered a good assay for the evaluation of free radicals scavenging. The statistical analysis showed that the storage at $5{ }^{\circ} \mathrm{C}$, induced a slight decrease but not significant in the free radical scavenging properties of orange beverages (Figure 5). These results were contradictory to those obtained by Piga et al. (2002) noticed an elevation in this activity for the tangerine juice during 15 days storage at $4{ }^{\circ} \mathrm{C}$. This could be due to differences in the type of stored product relating to differences in some parameters such as phytochemicals nature and their concentrations, $\mathrm{pH}$, and mode of preparation.

Concerning the other temperatures, the antiradical activity of extracts decreased significantly and gradually with temperature increase and storage progressing. This observation may be related to the decrease in phytochemical compounds (TPC, flavonoids, and carotenoids) in orange beverages (Klimczak et al., 2007).

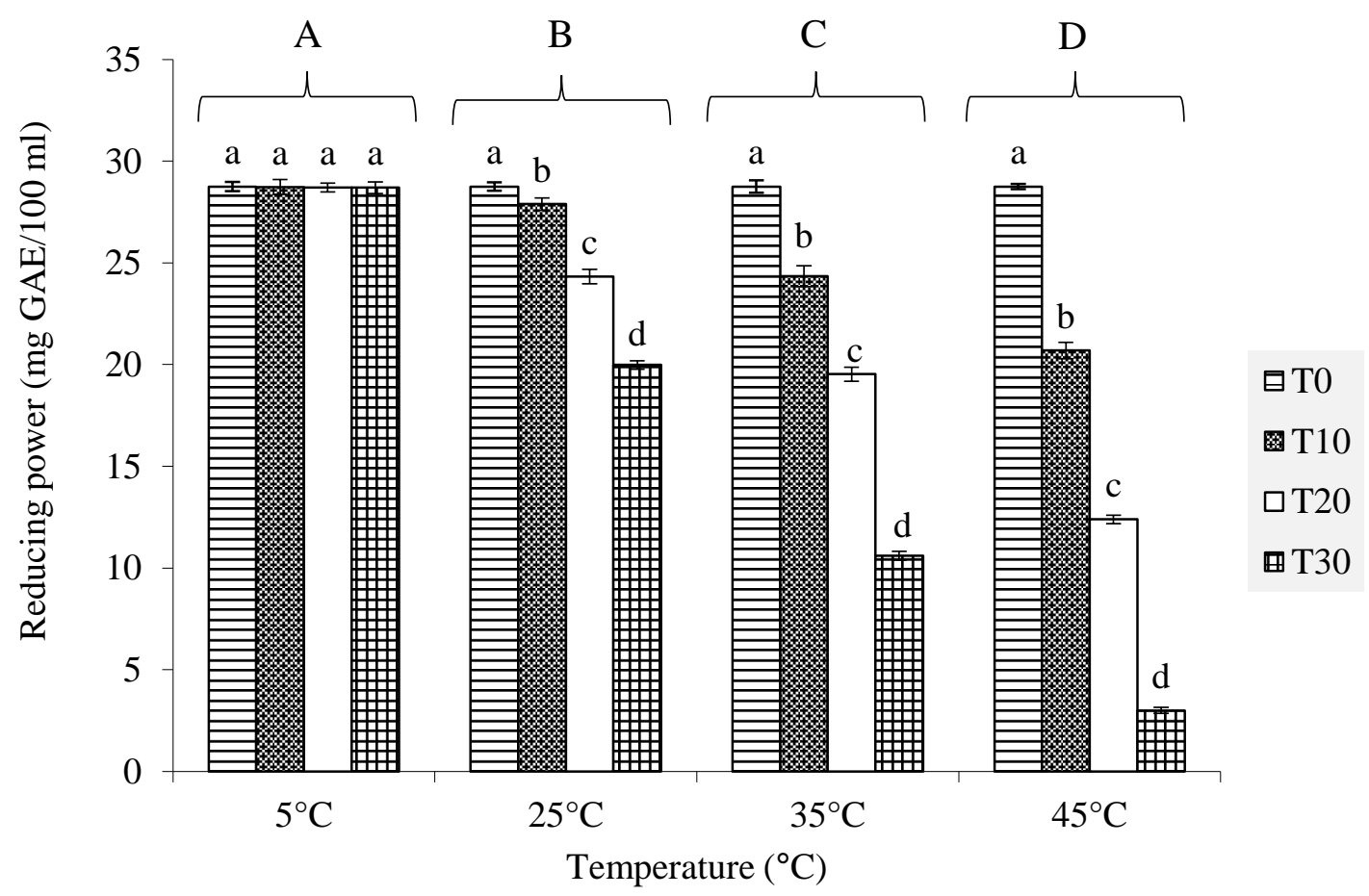

Figure 4. Influence of storage parameters on FRP of orange beverage.

Individual (lower-case letter) or grouped (upper-case letter) results with the same letters were statistically similar $(p<0.05$, MANOVA-LSD test). 


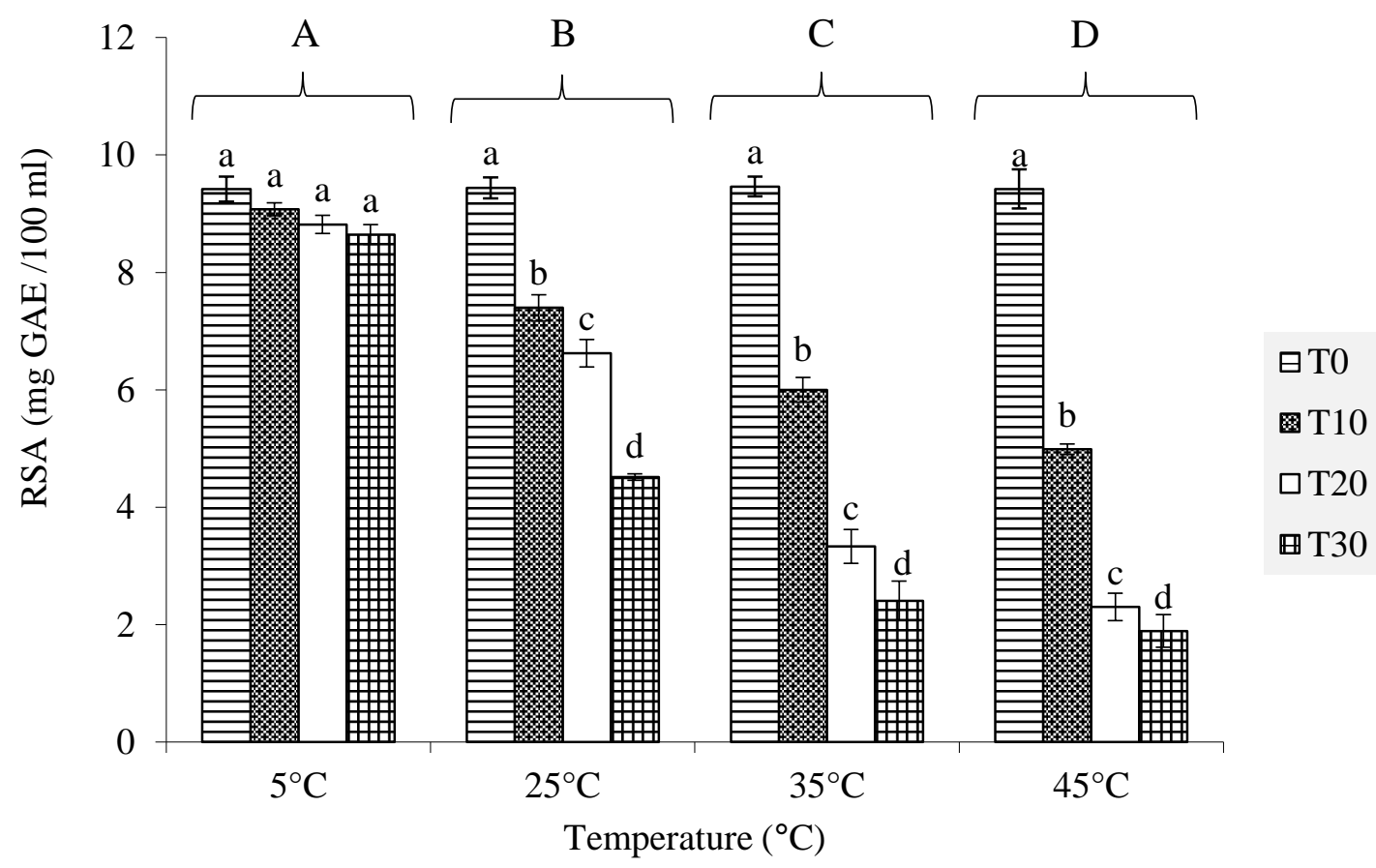

Figure 5. Influence of storage parameters on RSA of orange beverage.

Individual (lower-case letter) or grouped (upper-case letter) results with the same letters were statistically similar $(p<0.05$, MANOVA-LSD test).

\section{CONCLUSION}

The present work was conducted to study the influence of storage parameters (time and temperature) on phytochemical bioactive compounds and the antioxidant property of orange beverage. The results indicated that both storage parameters affected significantly the bioactive components and antioxidant capacity of the analyzed beverage. In fact, the storage at $5{ }^{\circ} \mathrm{C}$ allowed better preservation of carotenoids, total phenolics, and flavonoids. Even for the antioxidant activity, the better reducing powers and free-radical scavenger activities were obtained with the lower temperature. These activities significantly decreased with increasing conservation temperature and storage time. Therefore, it is recommended to store this drink in low temperatures and avoid ambient or high temperatures. This research also confirmed the interest in the consumption of fruit drinks that were a significant source of various antioxidants with trapping free radical properties in order to fight against oxidative stress.

\section{ACKNOWLEDGEMENTS}

This study was partially supported by the DGRSDT of Algeria.

\section{REFERENCES}

1. Ahmed, M. \& Eun, J.-B. (2018). Crit. Rev. Food Sci. Nutr. 58, 3159-3188. DOI: 3110.1080/10408398.10402017.11353480.

2. Álvarez-Fernández, M. A., Hornedo-Ortega, R., Cerezo, A. B., Troncoso, A. M. \& García-Parrilla, M. C. (2016). J. Agric. Food Chem. 64, 1367-1376. DOI: 1310.1021/acs.jafc.1365b05617.

3. Bachir bey, M., Meziant, L., Benchikh, Y. \& Louaileche, H. (2014). Int. Food Res. J. 21, 1477-1482. DOI: 1410.1016/j.foodchem.2014.1404.1054.

4. Bachir bey, M., Richard, G., Meziant, L., Fauconnier, M. L. \& Louaileche, H. (2017). J. Food Process. Pres. 41, e13164. DOI: 13110.11111/jfpp.16022. 
5. Bassama, J., Tamba, A., Ndong, M., Sarr, K. D. D. \& Cissé, M. (2021). Beverages 7, 1-12. DOI: 10.3390/beverages7010002.

6. Chen, J. \& Gao, Y. (2021). Sci. Technol. Food Indus. 42, 281-289. DOI: 210.13386/j.issn1100210306.2020090291.

7. Choi, M., Kim, G. \& Lee, H. (2002). Food Res. Inter. 35, 753-759. DOI: 710.1016/S09639969(1002)00071-00076.

8. Djeridane, A., Yousfi, M., Nadjemi, B., Boutassouna, D., Stocker, P. \& Vidal, N. (2006). Food chem. 97, 654-660. DOI: 610.1016/j.foodchem.2005.1004.1028.

9. FAOSAT (2021). http://www.fao.org/faostat/en/\#home Retrieved August 25, 2021.

10. Gülçin, İ., Oktay, M., Küfrevioğlu, Ö. İ. \& Aslan, A. (2002). J. ethnopharmacol. 79, 325-329. DOI: 310.1016/s0378-8741(1001)00396-00398.

11. Janciauskiene, S. (2020). Chronic. Obstr. Pulm. Dis. 7, 182. DOI: 110.15326/jcopdf.15327.15323.12019.10152.

12. Kähkönen, M. P., Hopia, A. I., Vuorela, H. J., Rauha, J.-P., Pihlaja, K., Kujala, T. S. \& Heinonen, M. (1999). J. Agric. Food Chem. 47, 3954-3962. DOI: 3910.1021/jf9901461..

13. Kausar, T., Shamim, F., Gorsi, F. I. \& Ainee, A. (2020). Pure Appl. Biol. 9, 219-228. DOI: $210.19045 /$ bspab.12020.90026.

14. Kırca, A. \& Cemeroğlu, B. (2003). Food chem. 81, 583-587. DOI: 510.1016/S0308-8146(1002)0050000509.

15. Klimczak, I., Małecka, M., Szlachta, M. \& Gliszczyńska-Świgło, A. (2007). J. Food Compos. Anal. 20, 313-322. DOI: 310.1016/j.jfca.2006.1002.1012.

16. Lin, C. \& Chen, B. (2005). Food chem. 90, 837-846. DOI: 810.1016/j.foodchem.2004.1005.1031.

17. Liu, R. H. (2003). Am. J. Clin. Nutr. 78, 517S-520S. DOI: 510.1093/ajcn/1078.1093.1517S.

18. Piga, A., Agabbio, M., Gambella, F. \& Nicoli, M. C. (2002). LWT-Food Sci.Technol. 35, 344-347. DOI: 310.1006/fstl.2001.0877.

19. Plaza, L., Sánchez-Moreno, C., De Ancos, B., Elez-Martínez, P., Martín-Belloso, O. \& Cano, M. P. (2011). LWT-Food Sci.Technol. 44, 834-839. DOI: 810.1016/j.lwt.2010.1012.1013.

20. Porto, M. R. A., Okina, V. S., Pimentel, T. C. \& Prudencio, S. H. (2017). Beverages 3, 36. Doi: 10.3390/beverages3030036.

21. Rodriguez-Amaya, D. B. (1997). Carotenoids and food preparation: the retention of provitamin A carotenoids in prepared, processed and stored foods. John Snow Incorporated/OMNI Project Arlington, VA.

22. Saad, A. M., Mohamed, A. S. \& Ramadan, M. F. (2020). Int. J. Veg. Sci. 27, 1-11. DOI: 10.1080/19315260.19312020.11779895.

23. Shams Najafabadi, N., Sahari, M. A., Barzegar, M. \& Hamidi Esfahani, Z. (2021). J. Food Process. Pres. 45, e15201. DOI: 15210.11111/jfpp.15201.

24. Sharifi-Rad, M., Anil Kumar, N. V., Zucca, P., Varoni, E. M., Dini, L., Panzarini, E., Rajkovic, J., Tsouh Fokou, P. V., Azzini, E., Peluso, I., Prakash Mishra, A., Nigam, M., El Rayess, Y., Beyrouthy, M. E., Polito, L., Iriti, M., Martins, N., Martorell, M., Docea, A. O., Setzer, W. N., Calina, D., Cho, W. C. \& Sharifi-Rad, J. (2020). Front. Physiol. 11, 694. DOI: 610.3389/fphys.2020.00694.

25. Soto-Zamora, G., Yahia, E. M., Brecht, J. K. \& Gardea, A. (2005). LWT-Food Sci. Technol. 38, 657-663. DOI: $610.1016 / j .1 w t .2004 .1008 .1005$.

26. Su, D., Wang, Z., Dong, L., Huang, F., Zhang, R., Jia, X., Wu, G. \& Zhang, M. (2019). LWT-Food Sci. Technol. 116, 108578. DOI: 108510.101016/j.lwt.102019.108578.

27. Suárez-Jacobo, Á., Saldo, J., Rüfer, C. E., Guamis, B., Roig-Sagués, A. X. \& Gervilla, R. (2012). J. Food Eng. 109, 291-300. DOI: 210.1016/j.jfoodeng.2011.1009.1007.

28. Touati, N., Tarazona-Díaz, M. P., Aguayo, E. \& Louaileche, H. (2014). Food chem. 145, 23-27. DOI: 10.1016/j.foodchem.2013.1008.1037.

29. Vinson, J. A., Su, X., Zubik, L. \& Bose, P. (2001). J. Agric. Food Chem. 49, 5315-5321. DOI: $5310.1021 /$ jf0009293. 
30. Zitha, E. Z. M., Araújo, A. B. S., Machado, P. d. S., Elias, H. H. d. S., Carvalho, E. E. N. \& Vilas Boas, E. V. d. B. (2021). Food Sci. Technol. Ahead of Print. DOI: 10.1590/fst.28221. 